Nazarova Karina,

Doctor of Sciences (Economics), Head of Department of financial analysis and audit Kyiv National University of Trade and Economics,

Kyiv, Ukraine

ORCID: 0000-0002-0133-7364

Resarcher ID: N-3427-2016

Kopotiienko Tetiana,

$\mathrm{PhD}$ in Economics,

Associate Professor of Department of financial analysis and audit

Kyiv National University of Trade and Economics,

Kyiv, Ukraine

ORCID: 0000-0001-6107-9937

Resarcher ID: I-2074-2018

Nezhyva Mariia,

$\mathrm{PhD}$ in Economics,

Senior Lecturer of Department of financial analysis and audit

Kyiv National University of Trade and Economics,

Kyiv, Ukraine

ORCID: 0000-0002-3008-5338

Resarcher ID: H-9408-2018

\title{
AUDIT IN THE CONDITIONS OF GEO-ECONOMIC CHANGES: STATUS AND IMPERATIVES OF DEVELOPMENT
}

The article is devoted to the research of the current state and imperatives of audit development in Ukraine in the conditions of geo-economic changes. It is determined that the main imperatives of the audit development are ensuring that it meets the quality criteria and raising the level of social responsibility of the audit. The tendencies of changes in the main parameters of the audit market development are investigated: number of subjects and volume of services from audit activity. A list of business entities that are of public interest, are subject to statutory audit and require increased control by the public regulator. The vectors of audit development in Ukraine are proposed.

Keywords: audit, imperatives of development, subjects of public interest.

Назарова Каріна, Копотієнко Тетяна, Нежива Марія. Аудит в умовах геоекономічних зрушень: стан та імперативи розвитку.

Стаття присвячена дослідженню сучасного стану та імперативів розвитку аудиту в Україні в умовах геоекономічних зрушень. Визначено, щя 
основними імперативами розвитку аудиту є забезпечення його відповідності критеріям якості та підвищення рівня соиіальної відповідальності аудиту. Досліджено тенденції зміни основних параметрів розвитку ринку аудиту: кількості суб'єктів та обсягу послуг від здійснення аудиторської діяльності. Представлено перелік суб'єктів господарювання, які становлять суспільний інтерес, підлягають обов'язковому аудиту та потребують посиленого контролю з боку суспільного регулятора. Запропоновано вектори розвитку аудиту в Украӥні.

Ключові слова: аудит, імперативи розвитку, суб'єкти суспільного інтересу.

Relevance of research topic. Globalization and intensification of economic processes, a significant deepening of European integration, determined the importance of developing and implementing its results - effective instruments for regulating corporate governance, accounting and auditing to form an efficient open-access economy. On September 1, 2017, the Association Agreement between Ukraine and the European Union entered into force in full [7], according to which Ukraine is obliged to gradually bring legislation to regulate the strategic spheres of the state in accordance with European norms. The said agreement identified issues of regulatory and legal regulation of enterprises, corporate governance, accounting and auditing. This resulted in qualitatively new requirements for audit activity in Ukraine and outlined the strategic guidelines for its development.

Formulation of the problem. The gradual introduction of the requirements for the reform of the audit activities declared in the Association Agreement between Ukraine and the European Union was commenced with the adoption of the Law of Ukraine «On Audit of Financial Statements and Audit Activities» [8]. At the same time, it is important to take into account the fact that many audit imperatives are not currently implemented. In particular, this concerns the legal regulation of audit, the implementation of international quality control standards, audit, review, other assurance and related services [5], their implementation in international practice of domestic auditors, improvement of the work of the public regulator of audit in Ukraine and others mandatory aspects of the implementation of international audit in national practice. A separate principle, conceptual issue is to improve the audit in the direction of developing its social responsibility and ensure compliance with two-level quality criteria (both at the national level and on the internal affiliate).

Analysis of recent researches and publications. Theoretical, methodological and practical principles of the development of independent professional audit are the subject of scientific interest of leading scientists, such as V.P. Bondar [1], G.M. Davydov, O.A. Petrik [2], V.S. Rudnitsky, O.M. Sarakhman [6] and others. In particular, V.P. Bondar [1] investigated the applied aspects of the use of working documentation in the framework of the audit of financial statements. Scientific achievements 
G.M. Davydov and O.A. Petrik [2] reveals the main trends in the regulation of audit activity in the European Union. The scientists systematized the basic norms of European legislation in the sphere of regulation of audit activity, studied the practice of organizing national audit systems in the states of the European Economic Area, and based on this experience, proposals were made for the organization of the national audit system in Ukraine. Such scholars as V.S. Rudnitsky and O.M. Sarakhman [6] examined the current problems, perspectives and peculiarities of carrying out the audit of payment card transactions. Recognizing the importance of the scientific work of scientists should be noted the relevance of continuing research on this topic.

The purpose of the article is to highlight the current state, conceptual issues of the development of audit and the imperatives of implementing international experience in the national practice of auditing in the conditions of geo-economic developments.

Presenting main material. Audit as a kind of professional activity is marked by a rather high degree of publicity of its results. The implications of providing audit services relate to a wide range of interested users of information and are not limited only to the effect on management of a particular specific entity. This leads to increased requirements for its quality and social responsibility, which is more clearly seen now on the example of the leading, economically developed (according to the World Bank rating) countries of the world. The main factor in ensuring compliance with the necessary criteria for the quality of the audit is, on the one hand, their consolidation at the legislative level, on the one hand, and their clear procedural provision.

It should be noted separately that in Ukraine, for a long time, there is a certain conflict between the number of unprofitable enterprises in the state and the audited conclusions. Thus, according to the State Statistics Service of Ukraine [3], the share of unprofitable enterprises is increasing every year: in 2017, the share of unprofitable enterprises amounted to $30.3 \%$, which is $3.3 \%$ more than in $2016(27.0 \%)$, and by $3.6 \%$ more than in 2015 (26.7\%). This, in turn, increases the role of auditing (both external, so-called independent, and internal), since owners and senior management of enterprises are growing the need to own an efficient and reliable information source for making managerial decisions aimed at improving the efficiency of management. The main objective of the audit of financial statements is to express an independent opinion of the auditor on its compliance in all material respects with the requirements of national accounting standards (standards), international financial reporting standards or other requirements [8]. However, there is not enough confidence that the audit results fully reflect the real financial and economic state of the enterprises and the level of objectivity and independence of the auditors during the inspections. Thus, in 2017, according to the official regulator, the Audit Chamber of Ukraine [9], 127 negative audit opinions and 51 waivers were expressed $(1,55 \%$ and $0,62 \%$ of the total number of audit findings respectively) According to the State Statistics Service of Ukraine, in 2017 the number of operating entities amounted to $1,805,144$ units, which is, in comparison with 2016 , lower by 60,487 units (in $2016-1,865,631$ units) and by 108808 units less than in 2015 (in 2015 - 1,974,439 units). The given statistics testify 
that the results of the audit were insufficiently reliable as the principle of continuity of activity was not observed when giving an auditor's report. The results of the audit should be accessible and understandable to both professional and nonprofessional users of information, which at the current stage of development of audit in Ukraine is also a problem.

After the entry into force of the Association Agreement with the European Union in full, in particular in the economic part, significant transformations have significantly increased; one of the conceptual issues is the mission, meaningful content and social responsibility of the audit.

The quality of the audit requires more scrutiny, so in Ukraine it is necessary to increase the control over the subjects of audit activity and the enterprises, institutions and organizations whose reporting is subject to the mandatory annual audit, namely, to increase the attention to the observance of their current Ukrainian and international activities legislation. The Law of Ukraine «On Audit of Financial Statements and Audit Activities» [8] introduces fundamental innovations in carrying out statutory audits on enterprises of public interest, limited liability companies and other mediumsized enterprises (Figure 1).

An audit, having moved to a new stage in its development, socially-oriented, should ensure the interests of society and guarantee its confidence in the audit results and the quality of information it provides to users. If the enterprise belongs to at least one of the groups listed in the figure, then it is an enterprise of public interest and, in accordance with the requirements of the current legislation of Ukraine, undertakes to undergo an annual mandatory audit.

The development of audit, in the context of European integration, has shown that the key point in the work of audit firms and auditors is the quality control of the audit services they provide.

The International Quality Control Standard 1 «Quality Control for firms that carry out audits and reviews of financial statements, as well as other assurance and related services» [5] states, that the objectives of the firm are to establish and maintain such a quality control system, which would give it enough assurance that: the firm itself and its personnel act in accordance with professional standards, legislative and regulatory requirements; and the reports provided by the firm or the task partners are in line with the circumstances.

The quality control by an audit firm guarantees users of financial statements audited by audit firms that have passed quality control, confidence and trust in the reliability of financial reporting data. As a consequence of this, there is an increase in trust in the audited company and in the auditing firm itself that carried out the verification.

The adoption of the Law of Ukraine «On Audit of Financial Statements and Audit Activities» and, accordingly, introduction of more stringent requirements for the certification of auditors and audit quality criteria, showed inconsistency with the established requirements of a significant proportion of active actors in audit activity. 
This led to a decrease in the number of audit engagement auditors and auditors in Ukraine in 2013-2017 (Figure 1).

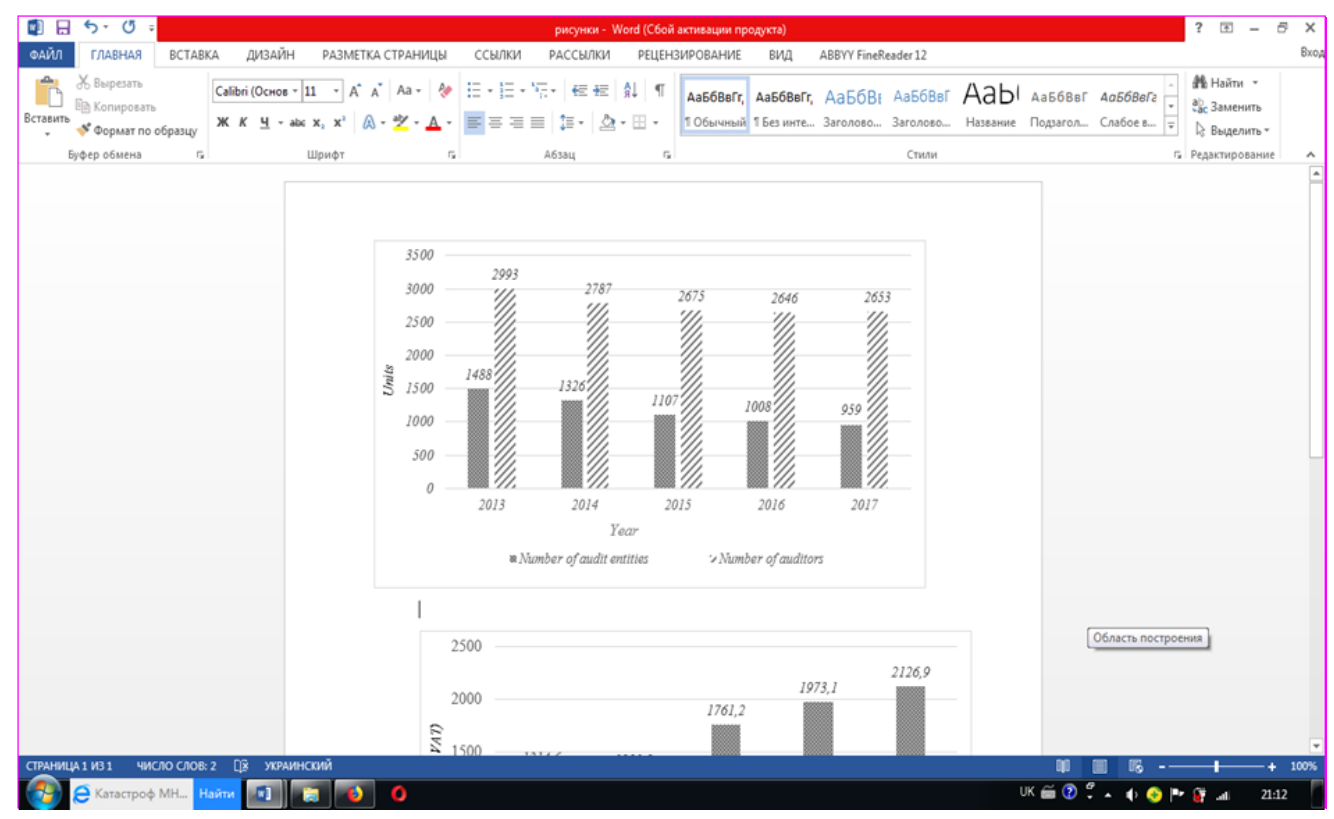

Fig. 1. Dynamics of the number of audit entities and auditors in 2013-2017

Source: author's development on the basis of [9].

Information shown in Fig. 1, indicates a tendency to decrease the number of auditors - by 189 persons (12.7\%) for 2013-2017, and the number of subjects of audit activity (by 340 firms, or 11.6\%). At the same time, the volume of services provided by the subjects of audit activity in Ukraine in 2013-2017, on the contrary, increases during the analyzed period (Fig. 2).

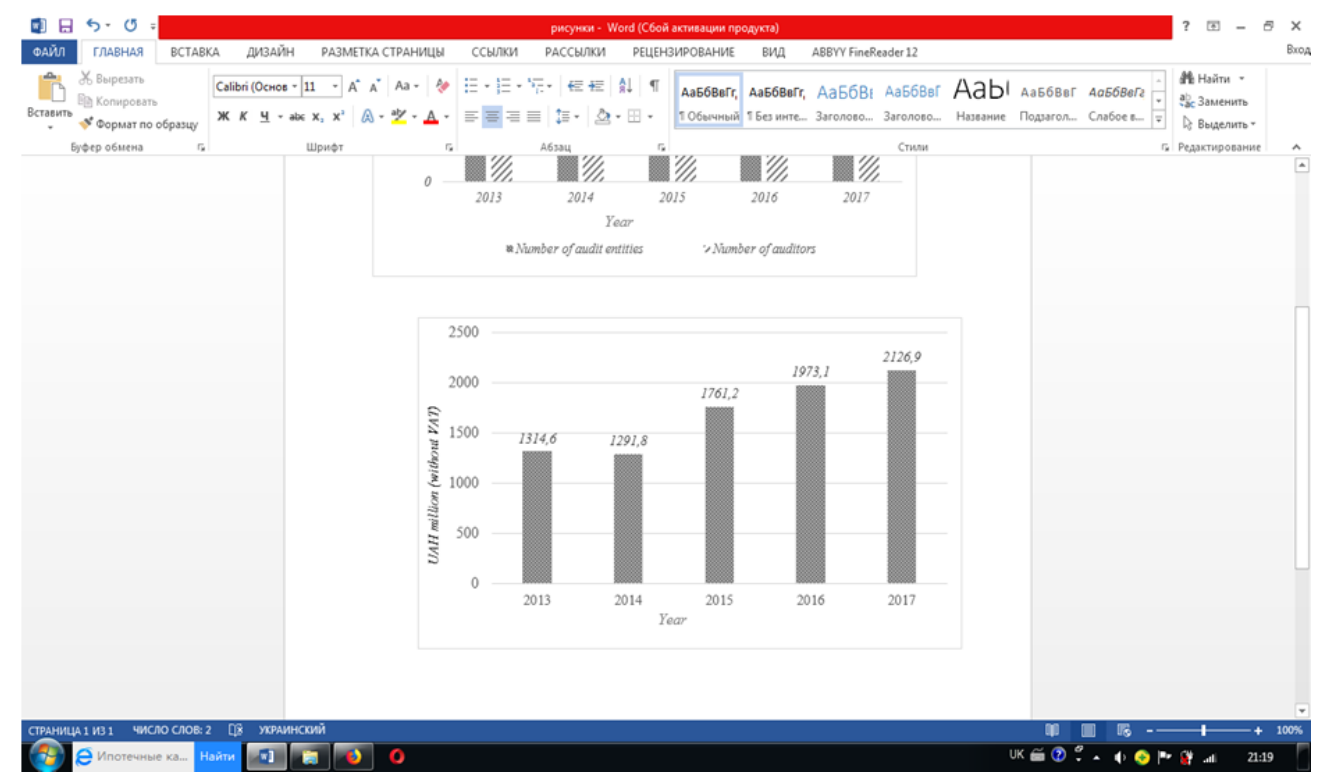

Fig. 2. Volume of services provided by the subjects of audit activity in 2013-2017 Source: author's development on the basis of [9]. 
The volume of services provided by the subjects of audit activity in 2013-2017 increased by 812272.2 thousand UAH, or $61.79 \%$. As a result, the volume of services rendered by one subject of audit activity is increasing, which confirms the positive tendency of audit development.

In Ukraine, the imperatives of conducting a qualitative audit are regulated by the Law of Ukraine «On Audit of Financial Statements and Audit Activities» [8]. According to the Audit Chamber of Ukraine [9], as of January 30, 2018 the audit of the quality control system of audit services was carried out by 951 auditing firms $(56,68 \%)$, of which $439(46.16 \%)$ were successfully tested, not passed -100 $(10.52 \%)$, did not pass at all $-412(43.32 \%)$. Consequently, most Ukrainian audit firms have not passed the test of the quality of the services they provide. Such results imply that in Ukraine the quality control system of audit firms is rather low, and audit firms, in turn, do not comply with the requirements of the current legislation on the conduct of their activities. As a result, the effectiveness of audit and user confidence in audit findings decreases, which is the main problem of our reality.

The European integration process of Ukraine in the area of audit led to significant significant economic transformations. Regarding the transformations in the field of audit, it should be noted that, when they are developed and implemented in order to achieve the high quality of the audit, it is necessary to take into account the requirements of Part 12 of Directive 2014/56/EU [4]: «Important to ensure the high quality of statutory audit within the Union. Therefore, all mandatory audit tasks should be performed on the basis of international auditing standards adopted by the commission. As the international standards for quality control, audit, inspection, other assurance and related services are designed to be acceptable for the audit of business entities of different sizes, types in all jurisdictions, the competent authorities of the member states should take into account the scale and complexity of the business of small businesses when assessing the scope of the application of international auditing standards. Any conditions or measures adopted by Member States in relation to this should not lead to the perceived auditor and audit firm being unable to perform a statutory audit in accordance with the requirements of international auditing standards. At the same time, member states will have the right to introduce additional national audit procedures or requirements only in cases where they derive from specific national legal requirements regarding the scope of statutory audit of annual or consolidated financial statements if these requirements are not covered by internationally accepted auditing standards, or if they enhance the quality and confidence of the annual financial statements and consolidated financial statements». Consequently, when transforming national legislation into international requirements, it is necessary to take into account the specifics of doing business with Ukrainian enterprises and the criteria and requirements of international standards of audit, as well as to strengthen control over compliance with these requirements by Ukrainian audit firms and auditors. 
The compliance of auditing firms and auditors with the requirements of the current legislation is mandatory. Their violation leads to the fact that the subject of audit activity may not pass the quality control and, as a consequence, be deprived of the right to provide audit services in general. It depends on this on the quality of the audit and the correctness of the conclusion reached regarding the reliability of the financial reporting data that users of the financial statements are targeting.

Conclusion. Despite the implementation of a number of significant measures to improve the audit activity in Ukraine, many issues regarding the quality assurance of the audit are currently unresolved. Multicomponent cooperation with the European Union on corporate governance, accounting and auditing will allow the use of leading foreign experience and adapt the norms of national legislation in the field of regulation of audit activity to European ones. This will ensure that the norms of regulation of activities of public interest entities in Ukraine meet the requirements of international standards. This will promote more effective protection of the rights of shareholders and creditors, minimizing the risks of company raider attacks, and, consequently, increasing the trust of foreign investors and improving the investment climate in the state. The identified audit engagements can increase the quality of the audit and, as a consequence, the trust of users of information.

\section{REFERENCES}

1. Bondar V. P. (2018) Robochi dokumenty audytora ta kontrol yakosti audytu finansovoi zvitnosti, shcho skladena na vymohu inozemnoho investora [Auditor's working documents and control of audit quality of financial reporting that required by foreign investor]. Statystyka Ukrainy - Statistics of Ukraine, 1, 68-76. Retrieved from http://194.44.12.92:8080/jspui/bitstream/123456789/3427/1/68-76.pdf [in Ukrainian].

2. Davydov H. M. \& Petryk O. A. (2014) Analiz praktyky orhanizatsii natsionalnykh system audytu $\mathrm{v}$ derzhavakh Yevropeiskoho ekonomichnoho prostoru [Analysis of the practice of organization of national audit systems in the countries of the European economic area]. Naukovi pratsi Kirovohradskoho natsionalnoho tekhnichnoho universytetu. Ekonomichni nauky - Scientific papers of Kirovograd National Technical University. Economic sciences, 26, 151-158. Retrieved from file:///C:/Users/PRIOM/Downloads/Npkntu_e_2014_26_23.pdf [in Ukrainian].

3. Derzhavna sluzhba statystyky Ukrainy [State Statistics Service of Ukraine]. ukrstat.gov.ua. Retrieved from http://www.ukrstat.gov.ua/

4. Dyrektyva 2014/56/IeS Yevropeiskoho parlamentu ta Rady vid 16.04.2014 [Directive 2014/56/EU of the European Parliament and of the Council]. zakon.rada.gov.ua. Retrieved from https://zakon.rada.gov.ua/laws/show/984_002-14 [in Ukrainian]. 
5. Handbook of International QualityControl, Auditing, Review, Other Assuranceand Related Services Pronouncements. 2015 Edition. Volume I. New York: International Federation of Accountants. 2016. 1249 p.

6. Rudnytskyi V. S. \& Sarakhman O. (2016) Audyt operatsii bankiv iz platizhnymy kartkamy yak osnovna baza ukhvalennia upravlinskykh rishen [Audit of payment card banks as the main basis for making management decisions]. Visnyk Universytetu bankivskoi spravy - Journal of University of Banking, 1-2, 78-83. Retrieved from file:///C:/Users/PRIOM/Downloads/VUbsNbU_2016_1-2_15.pdf [in Ukrainian].

7. Uhoda pro asotsiatsiiu mizh Ukrainoiu, z odniiei storony, ta Yevropeiskym Soiuzom, Yevropeiskym spivtovarystvom $\mathrm{z}$ atomnoi enerhii i yikhnimy derzhavamychlenamy, z inshoi storony vid 27.06.2014 [Association Agreement between Ukraine, of the one part, and the European Union, the European Atomic Energy Community, and their Member States, of the other part]. zakon.rada.gov.ua. Retrieved from https://zakon.rada.gov.ua/laws/show/984_011 [in Ukrainian].

8. Zakon Ukrainy «Pro audyt finansovoi zvitnosti ta audytorsku diialnist» №2258-19/ 2017 vid 21.12.2017 [Law of Ukraine «On Audit of Financial Statements and Audit Activities»]. (n.d.) zakon.rada.gov.ua. Retrieved from http://zakon2. rada.gov.ua/laws/show/2258-19 [in Ukrainian].

9. Zvit Audytorskoi palaty Ukrainy do Kabinetu Ministriv Ukrainy za 2017 rik. [Report of the Audit Chamber of Ukraine to the Cabinet of Ministers of Ukraine for 2017]. www.apu.com.ua. Retrieved from https://www.apu.com.ua/2018/09/29/\%d0\% b7\%d0\%b2\%d1\%96\%d1\%82\%d0\%bd\%d1\%96\%d1\%81\%d1\%82\%d1\%8c/. 